\author{
Research Article \\ www.ijrap.net (ISSN:2229-3566)
}

\title{
PHARMACEUTICAL AND ANALYTICAL STUDY ON DIFFERENT PARTS OF ASHOKA [SARACA ASOCA ROXB. DE WILDE.]
}

Soumya Saraswathi $\mathrm{M}^{1 *}$, Subrahmanya Padyana ${ }^{2}$

${ }^{1}$ Professor, Department of Ayurveda Samhita and Siddhanta, Alva's Ayurveda Medical College, Moodbidri, Karnataka, India

${ }^{2}$ Director, Alva's Traditional Medicine Archive (ATMA) \& Research Centre, Moodbidri, Karnataka, India

Received on: 18/07/21 Accepted on: 05/10/21

\author{
*Corresponding author \\ E-mail: drsoumyasp82@gmail.com
}

DOI: 10.7897/2277-4343.1205137

\begin{abstract}
Presently Ayurvedic medicines are becoming ultimate medicine rather than alternative medicine. The plant Asoka (Saraca asoca Roxb.)is one of the important plants of the Indian system of medicine known for its numerous pharmacological activities. After analysing the physicochemical and phytochemical properties of different parts of Ashoka, various formulations of different parts of Ashoka have been prepared. Hence, to establish the different parts of Ashoka as medicine, an attempt has been made to conduct a pharmaceutical and analytical study on various parts of Ashoka. In the present study, it can be conclusively said that the face pack of the root powder is beneficial in blackish discolouration of the face, root ointment in acne and blackish discolouration of the face, stem syrup is beneficial in eczema and acne, stem powder soap is useful in skin disease, bark Kashaya in gynaecological disorders, bark syrup in dysfunctional uterine bleeding and anaemia, bark granules in general debility and anaemia, tender leaves Tambuli in gastritis, leaf ointment in acne, flower Tambuli in gastritis and menorrhagia, flower syrup in gastritis and seed powder is useful in urinary calculi and burning micturition. The pharmaceutical evaluation of all the prepared products of Ashoka was done and analysed systematically. The multiple formulations of different parts of Ashoka (S. asoca) which are useful as food and medicine are the outcomes of the present study.
\end{abstract}

Key Words: Ethno-medico-botanical study, Ashoka, Saraca asoca Roxb., Moodbidri, Pharmaceutical Study, Analytical Study.

\section{INTRODUCTION}

The use of plants for medicinal purposes dates back to time immemorial. Herbal medicine was a part of human life, later replaced by synthetic medicines. But, presently Ayurvedic medicines are becoming ultimate medicine rather than alternative medicine.

Ayurveda, the traditional system of medicine continues to be widely practised from many angles. Rising population, inadequate supply of drugs, the prohibitive cost of treatments, side effects of several synthetic drugs and development of resistance to currently used drugs for infectious diseases have led to increased emphasis on the use of plant material as a source of medicines for a wide variety of human ailments.

According to an estimate of the World Health Organization (WHO), about $80 \%$ of the world population still uses herbs and other traditional medicines for their primary health care needs ${ }^{1}$.

The plant Asoka (Saraca asoca Roxb.) is one of the most sacred and legendry trees of India. It is one of the important plants of the Indian system of medicine known for its numerous pharmacological activities. The plant Ashoka is mentioned in classics for its utility in various gynaecological disorders by using bark as its useful part. But, in the folklore practice, apart from its utility in gynaecological disorders, the flowers in the form of milkshake or syrup or Tambuli (food preparation) is beneficial in gastritis, tender leaves in acne vulgaris, stem in case of skin diseases, roots in blackish discolouration on face etc ${ }^{2}$.
Thus, based on the folklore information of medicinal usage of Ashoka and also after analysing its physicochemical and phytochemical properties ${ }^{3}$ of different parts of Ashoka, various formulations of different parts of Ashoka have been prepared. Hence, to establish the different parts of Ashoka as medicine, an attempt has been made to conduct a pharmaceutical and analytical study on various parts of Ashoka.

\section{MATERIALS AND METHODS}

Different parts of Ashoka (Saraca asoca Roxb.) such as root, stem, stem bark, tender leaves, matured leaves, flowers and seeds are collected and the voucher specimen is deposited in the Alva's Traditional Medicine Archive (ATMA) and Research Centre (Voucher Specimen Number ATMA/2021/SSM/05). The collected parts of Ashoka are subjected to preliminary phytochemical studies and prepared various formulations based on the information gathered during ethnomedical documentation and classical principles of Ayurveda. After the preparations of these various formulations, it was subjected to analytical study.

\section{Pharmaceutical study ${ }^{4}$}

\section{Ashoka Root Face Pack Powder}

$2 \mathrm{~kg}$ of Ashoka root is taken and it is cleaned properly to remove physical impurities. Then it is dried properly. The dried roots are powdered with the help of a pulveriser and sieved. 


\section{Ashoka Root Ointment}

Table 1: Ingredients of Ashoka Root ointment

\begin{tabular}{|c|c|}
\hline Name & Quantity \\
\hline Ashoka Root coarse powder & $500 \mathrm{~g}$ \\
\hline Ashoka root fine powder & $80 \mathrm{~g}$ \\
\hline Coconut oil & $500 \mathrm{ml}$ \\
\hline Bee wax & $100 \mathrm{~g}$ \\
\hline Water & 4 litre \\
\hline
\end{tabular}

Ashoka root is taken and it is cleaned properly to remove physical impurities. Then it is dried properly. The dried roots are powdered coarsely with the help of a pulveriser. One part of the coarse powder of the root is boiled with 8 parts of water and reduced to half and filtered. $80 \mathrm{~g}$ of fine powder of the root is taken and mixed with a little amount of water and made into a paste. This paste is boiled with $500 \mathrm{ml}$ of oil and 2 liters of Kashaya till the signs of the endpoint of Taila Paka is observed. Then it is filtered $500 \mathrm{ml}$ of prepared Ashoka root oil is taken in a dry, clean vessel and heated over low flame and temperature is noted. When the temperature reaches $60^{\circ} \mathrm{C}, 100 \mathrm{~g}$ of small pieces of Beeswax were slowly added to the vessel containing the Taila and stirred carefully until it dissolves completely. After complete dissolution of Beeswax, the contents were filtered through a clean cloth to separate insoluble particles possibly present in Beeswax. $30 \mathrm{gm}$ of the prepared ointment filled in each ointment tubes immediately, before it gets solidify and labelled.

\section{Ashoka Stem Syrup}

Table 2: Ingredients of Ashoka stem syrup

\begin{tabular}{|c|c|}
\hline Name & Quantity \\
\hline Ashoka Stem coarse powder & $2 \mathrm{~kg}$ \\
\hline Water & 8 litre \\
\hline Sugar & $4 \mathrm{~kg}$ \\
\hline
\end{tabular}

Ashoka stem is taken and it is cleaned properly to remove physical impurities. Then it is dried properly. The dried stem is powdered coarsely with the help of a pulveriser. 1 part of the coarse powder of the stem is boiled with 8 parts of water and reduced to half and filtered. 4 litres of prepared Kashaya are taken and $4 \mathrm{~kg}$ of sugar is added and boiled till the signs of the endpoint of syrup are observed. $0.5 \%$ of the mixture of methylparaben and propylparaben is added to the syrup as a preservative. $200 \mathrm{ml}$ of syrup is measured and filled in each bottle and stored properly.

\section{Ashoka Stem powder Soap}

Table 3: Ingredients of Ashoka stem oil

\begin{tabular}{|c|c|}
\hline Name & Quantity \\
\hline Ashoka Stem coarse powder & $1 \mathrm{~kg}$ \\
\hline Water & 8 litre \\
\hline Ashoka stem fine powder & $150 \mathrm{~g}$ \\
\hline Coconut oil & 1 litre \\
\hline
\end{tabular}

Table 4: Ingredients of Ashoka stem soap

\begin{tabular}{|c|c|}
\hline Name & Quantity \\
\hline Ashoka Stem Oil & 1 litre \\
\hline Water & $750 \mathrm{ml}$ \\
\hline Sodium Hydroxide (Caustic Soda) & $200 \mathrm{~g}$ \\
\hline Beeswax & $50 \mathrm{~g}$ \\
\hline
\end{tabular}

Ashoka stem is taken and it is cleaned properly to remove physical impurities. Then it is dried properly. The dried stem is powdered coarsely with the help of a pulveriser. 1 part of the coarse powder of the stem is boiled with 8 parts of water and reduced to half and filtered. $150 \mathrm{gm}$ of fine powder of the stem is taken and mixed with a little amount of water and made into a paste. This paste is boiled with $1,000 \mathrm{ml}$ of oil and 2 litres of Kashaya till the signs of the endpoint of Taila Paka is observed. Then it is filtered. The $200 \mathrm{gm}$ of sodium hydroxide dissolved in $750 \mathrm{ml}$ of water, stirred well for 10 minutes and kept overnight. The next day morning the earlier prepared 1 litre Ashoka stem oil is added slowly to the Sodium hydroxide mixture and stirred continuously for 15 minutes. Now add 50 gm of melted bee wax gently and stirred well. This mixture is poured into the tray and dried under sunshine for 4 hours. Then made into pieces of required shapes and sizes.

\section{Ashoka Bark Kashaya}

Table 5: Ingredients of Ashoka bark Kashaya

\begin{tabular}{|c|c|}
\hline Name & Quantity \\
\hline Ashoka Stem Bark coarse powder & $2 \mathrm{~kg}$ \\
\hline Water & 16 litre \\
\hline
\end{tabular}

Ashoka Bark is taken and it is cleaned properly to remove physical impurities. Then it is dried properly. The dried bark is powdered coarsely with the help of a pulveriser. 1 part of the coarse powder of the bark is boiled with 8 parts of water and reduced to one fourth and filtered. 20 gm of Methylparaben and propylparaben is added as a preservative.

\section{Ashoka Bark Syrup}

Table 6: Ingredients of Ashoka bark syrup

\begin{tabular}{|c|c|}
\hline Name & Quantity \\
\hline Ashoka Stem Bark coarse powder & $2 \mathrm{~kg}$ \\
\hline Water & 8 litre \\
\hline Sugar & $4 \mathrm{~kg}$ \\
\hline
\end{tabular}

Ashoka stem bark is taken and it is cleaned properly to remove physical impurities. Then it is dried properly. The dried stem is powdered coarsely with the help of a pulveriser. 1 part of the coarse powder of the stem is boiled with 8 parts of water and reduced to half and filtered. 4 litres of prepared Kashaya are taken and $4 \mathrm{~kg}$ of sugar is added and boiled till the signs of the endpoint of syrup is observed. $0.5 \%$ of the mixture of methylparaben and propylparaben is added to the syrup as a preservative. $200 \mathrm{ml}$ of syrup is measured and filled in each bottle and stored properly.

\section{Ashoka Bark Granules}

Table 7: Ingredients of Ashoka Bark Granules

\begin{tabular}{|c|c|}
\hline Name & Quantity \\
\hline Ashoka Stem Bark coarse powder & $2 \mathrm{~kg}$ \\
\hline Ashoka Stem Bark fine powder & $100 \mathrm{gm}$ \\
\hline Water & 8 litre \\
\hline Sugar & $4 \mathrm{~kg}$ \\
\hline
\end{tabular}

Ashoka stem bark is taken and it is cleaned properly to remove physical impurities. Then it is dried properly. The dried stem is powdered coarsely with the help of a pulveriser. 1 part of the coarse powder of the stem is boiled with 8 parts of water and reduced to half and filtered. 4 litres of prepared Kashaya is taken and to this $4 \mathrm{~kg}$ of sugar is added and boiled till the signs of the endpoint of syrup are observed. Then $100 \mathrm{gm}$ of fine powder of Ashoka bark is added and stirred well, till to form granules. 


\section{Ashoka Tender Leaf Tambuli}

Two kg of Ashoka tender leaves are taken and it is cleaned properly to remove physical impurities. These fresh leaves are ground with coconut and then added buttermilk and salt which is eaten during lunch by mixing with rice.

\section{Ashoka Leaf Ointment}

Table 8: Ingredients of Ashoka leaf ointment

\begin{tabular}{|c|c|}
\hline Name & Quantity \\
\hline Ashoka Leaf coarse powder & $500 \mathrm{~g}$ \\
\hline Ashoka leaf fine powder & $80 \mathrm{~g}$ \\
\hline Coconut oil & $500 \mathrm{ml}$ \\
\hline Beeswax & $100 \mathrm{~g}$ \\
\hline Water & 4 litre \\
\hline
\end{tabular}

Ashoka leaf is taken and it is cleaned properly to remove physical impurities. Then it is dried properly. The dried roots are powdered coarsely with the help of a pulveriser. 1 part of the coarse powder of the leaf is boiled with 8 parts of water and reduced to half and filtered. $80 \mathrm{~g}$ of fine powder of the leaf is taken and mixed with a little amount of water and made into a paste. This paste is boiled with $500 \mathrm{ml}$ of oil and 2 liters of Kashaya till the signs of the endpoint of Taila Paka is observed. Then it is filtered. $500 \mathrm{ml}$ of prepared Ashoka leaf oil is taken in a dry, clean vessel and heated over low flame and temperature is noted. When the temperature reaches $60{ }^{\circ} \mathrm{C}, 100 \mathrm{~g}$ of small pieces of Beeswax were slowly added to the vessel containing the Taila and stirred carefully until it dissolves completely. After complete dissolution of Beeswax, the contents were filtered through a clean cloth to separate insoluble particles possibly present in Beeswax. $30 \mathrm{gm}$ of the prepared ointment filled in each ointment tubes immediately, before it gets solidifies and labelled.

\section{Ashoka Flower Powder- Tambuli}

$2 \mathrm{~kg}$ of Ashoka flower is taken and it is cleaned properly to remove physical impurities. Then it is dried properly under shade. The dried flowers are powdered with the help of a pulveriser and sieved. This powder is ground with coconut and then added buttermilk and salt which is eaten during lunch by mixing with rice.

Table 10: Ashoka Root Face Pack Powder

\begin{tabular}{|c|c|}
\hline Test & Result \\
\hline Organoleptic & \\
Roopa (Colour) & Light Grey \\
Rasa (Taste) & Tikta, Kashaya \\
Gandha (Odour) & Pleasant \\
Sparsha (Touch) & Slightly rough \\
\hline Loss on drying & $5.40 \%$ \\
\hline pH & 5.50 \\
\hline Water Soluble extract & $14.50 \%$ \\
\hline Total Ash & $7.20 \%$ \\
\hline Acid insoluble ash & $0.40 \%$ \\
\hline Water Soluble ash & $2.60 \%$ \\
\hline
\end{tabular}

Ashoka Flower Syrup

Table 9: Ashoka Flower syrup

\begin{tabular}{|c|c|}
\hline Name & Quantity \\
\hline Ashoka flower coarse powder & $2 \mathrm{~kg}$ \\
\hline Water & 8 litre \\
\hline Sugar & $4 \mathrm{~kg}$ \\
\hline
\end{tabular}

Ashoka flower is taken and it is cleaned properly to remove physical impurities. Then it is dried properly under sunlight. The dried flowers are powdered coarsely with the help of a pulveriser. 1 part of the coarse powder of the flower is boiled with 8 parts of water and reduced to half and filtered. 4 litres of prepared Kashaya are taken and $4 \mathrm{~kg}$ of sugar is added and boiled till the signs of the endpoint of syrup is observed. $0.5 \%$ of the mixture of methylparaben and propylparaben is added to the syrup as a preservative. $200 \mathrm{ml}$ of Syrup is measured and filled in each bottle and stored properly.

\section{Ashoka Seed Powder}

$2 \mathrm{~kg}$ of Ashoka seed is taken and it is cleaned properly to remove physical impurities. Then it is made into small pieces and dried properly under shade. The dried seeds are powdered with the help of a pulveriser and sieved.

\section{Pharmaceutico-Analytical Study}

Various preparations by using different parts of Ashoka are prepared based on the folklore information gathered during the preliminary survey and relevant standardization tests are done such as tests for Particle size, Bulk density, Tap density, Refractive Index, Brix Value, Iodine value, Saponification value, Viscosity, Specific gravity, Rancidity Test (Kreis test) and Spreadability. ${ }^{5}$

\section{RESULTS}

\section{Pharmaceutical and analytical study}

After collecting the folklore information on different parts of Ashoka and analysing the preliminary studies, the standardisation of the following pharmaceutical preparations was done.

Table 11: Ashoka Root Ointment

\begin{tabular}{|c|c|}
\hline Tests & Results \\
\hline Organoleptic & \\
Roopa (Colour) & Yellowish-brown \\
Gandha (Odour) & Characteristic \\
Sparsha (Touch) & $1.85 \%$ \\
\hline Loss on drying & 5.80 \\
\hline $\mathrm{pH}$ & 1.482 \\
\hline Refractive Index (Oil) & 13 \\
\hline Spreadability (gm.cm/s) & $48.72 \%$ \\
\hline Viscosity (Oil) & Negative \\
\hline Rancidity & 106.68 \\
\hline Iodine value (Oil) & $196 \mathrm{mg} / \mathrm{g}$ \\
\hline Saponification value (Oil) &
\end{tabular}


Table 12: Ashoka Stem syrup

\begin{tabular}{|c|c|}
\hline Tests & Results \\
\hline Organoleptic & \\
Roopa (Appearance/Colour) & Reddish-brown \\
Rasa (Taste) & Sweet \\
Gandha (Odour) & Characteristic \\
Sparsha (Touch/ Consistency) & Thick Fluid \\
\hline $\mathrm{pH}$ & 6.75 \\
\hline Viscosity & $45.55 \%$ \\
\hline Specific gravity & 1.24 \\
\hline Brix value & $50 \%$ \\
\hline
\end{tabular}

Table 14: Ashoka Bark Kashaya

\begin{tabular}{|c|c|}
\hline Tests & Results \\
\hline Organoleptic & \\
Roopa (Colour) & Greyish brown \\
Rasa (Taste) & Astringent \\
Gandha (Odour) & Pleasant \\
Sparsha (Touch/Consistency) & Thin in consistency \\
\hline Loss on drying (powder) & $5.80 \%$ \\
\hline $\mathrm{pH}$ & 6.45 \\
\hline
\end{tabular}

Table 16: Ashoka bark granules

\begin{tabular}{|c|c|}
\hline Tests & Results \\
\hline Organoleptic & \\
Roopa (Colour) & Brownish \\
Rasa (Taste) & Sweet \\
Gandha (Odour) & Aromatic \\
Sparsha (Touch) & Rough \\
\hline Loss on drying & $1.25 \%$ \\
\hline pH & $6.70 \%$ \\
\hline Particle size & 2 to $3 \mathrm{~mm} \mathrm{size}$ \\
\hline Bulk Density & $0.725 \mathrm{gm} / \mathrm{ml}$ \\
\hline Tap Density & $0.865 \mathrm{gm} / \mathrm{ml}$ \\
\hline Brix value & $66 \%$ \\
\hline
\end{tabular}

Table 18: Ashoka Leaf ointment

\begin{tabular}{|c|c|}
\hline Tests & Results \\
\hline $\begin{array}{c}\text { Organoleptic } \\
\text { Roopa (Colour) } \\
\text { Gandha (Odour) } \\
\text { Sparsha (Touch) } \\
\end{array}$ & $\begin{array}{c}\text { Greenish Yellow } \\
\text { Characteristic pleasant } \\
\text { Soft and Smooth }\end{array}$ \\
\hline Loss on drying & $1.27 \%$ \\
\hline $\mathrm{pH}$ & 5.63 \\
\hline Refractive Index & 1.449 \\
\hline Spreadability (gm.cm/s) & 13 \\
\hline Viscosity (Oil) & $45.86 \%$ \\
\hline Rancidity & Negative \\
\hline Iodine value (Oil) & 104.52 \\
\hline Saponification value (Oil) & $183 \mathrm{mg} / \mathrm{g}$ \\
\hline
\end{tabular}

Table 20: Ashoka flower syrup

\begin{tabular}{|c|c|}
\hline Tests & Results \\
\hline Organoleptic & Reddish Brown \\
Roopa (Colour) & Sweet \\
Rasa (Taste) & Characteristic pleasant \\
Gandha (Odour) & Viscous \\
Sparsha (Touch) & 5.85 \\
\hline pH & $46.85 \%$ \\
\hline Viscosity & 1.27 \\
\hline Specific gravity & $55 \%$ \\
\hline Brix Value &
\end{tabular}

Table 13: Ashoka Stem powder soap

\begin{tabular}{|c|c|}
\hline Tests & Results \\
\hline Organoleptic & \\
Roopa (Colour) & Cream \\
Gandha (Odour) & Pleasant \\
Sparsha (Touch) & Smooth \\
\hline Refractive index (Oil) & 1.461 \\
\hline Viscosity (Oil) & $49.42 \%$ \\
\hline Iodine Value (Oil) & 52.55 \\
\hline Saponification Value (Oil) & $178.30 \mathrm{mg} / \mathrm{gm}$ \\
\hline
\end{tabular}

\section{Table 15: Ashoka Bark syrup}

\begin{tabular}{|c|c|}
\hline Tests & Results \\
\hline Organoleptic & \\
Roopa (Colour) & Yellowish-brown \\
Rasa (Taste) & Sweet \\
Gandha (Odour) & Pleasant \\
Sparsha (Touch/ Consistency) & Viscous \\
\hline $\mathrm{pH}$ & 6.35 \\
\hline Viscosity & $48.42 \%$ \\
\hline Specific gravity & 1.28 \\
\hline Brix value & $50 \%$ \\
\hline
\end{tabular}

Table 17: Ashoka Tender Leaves

\begin{tabular}{|c|c|}
\hline Tests & Results \\
\hline Organoleptic & \\
Roopa (Colour) & Coppery red \\
Rasa (Taste) & Astringent and bitter \\
Gandha (Odour) & Characteristic \\
Sparsha (Touch) & Smooth \\
\hline Loss on drying & $7.25 \%$ \\
\hline pH & 6.60 \\
\hline Protein & $12.28 \%$ \\
\hline Carbohydrate & $8.83 \%$ \\
\hline Vitamin C & $1.24 \%$ \\
\hline
\end{tabular}

Table 19: Ashoka flower powder

\begin{tabular}{|c|c|}
\hline Tests & Results \\
\hline Organoleptic & \\
Roopa (Colour) & Reddish Brown \\
Rasa (Taste) & Sweet and astringent \\
Gandha (Odour) & Characteristic pleasant \\
Sparsha (Touch) & Smooth \\
\hline Loss on drying & $7.75 \%$ \\
\hline $\mathrm{pH}$ & 5.85 \\
\hline Protein Estimation & $15.65 \%$ \\
\hline Carbohydrate Estimation & $24.55 \%$ \\
\hline Vitamin C Estimation & $3.65 \%$ \\
\hline
\end{tabular}

Table 21: Ashoka seed powder

\begin{tabular}{|c|c|}
\hline Tests & Results \\
\hline Organoleptic & \\
Roopa (Colour) & Grey \\
Rasa (Taste) & Sweet and Astringent \\
Gandha (Odour) & Pleasant \\
Sparsha (Touch) & Smooth \\
\hline Loss on drying & $6.10 \%$ \\
\hline pH & 6.40 \\
\hline Water Soluble extract & $26.30 \%$ \\
\hline Total Ash & $4.85 \%$ \\
\hline Acid insoluble ash & $0.55 \%$ \\
\hline Water Soluble ash & $2.25 \%$ \\
\hline Protein Estimation & $16.12 \%$ \\
\hline Carbohydrate Estimation & $26.45 \%$ \\
\hline
\end{tabular}




\section{PHOTOS OF DIFFERENT PRODUCTS OF ASHOKA}

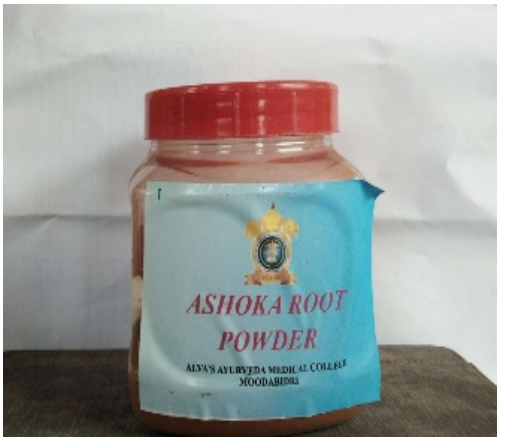

Root- face pack Powder

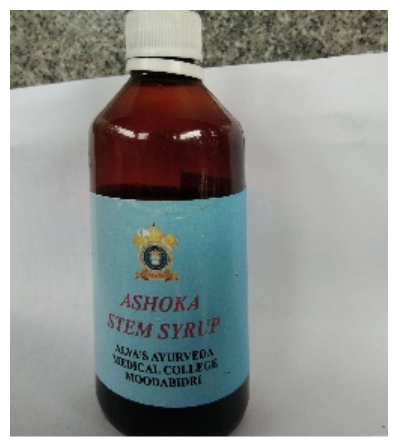

Stem Syrup

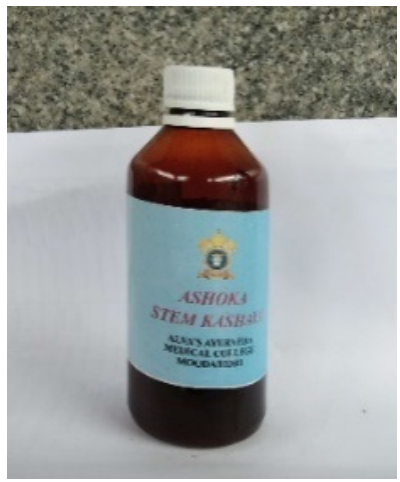

Stem bark Kashaya

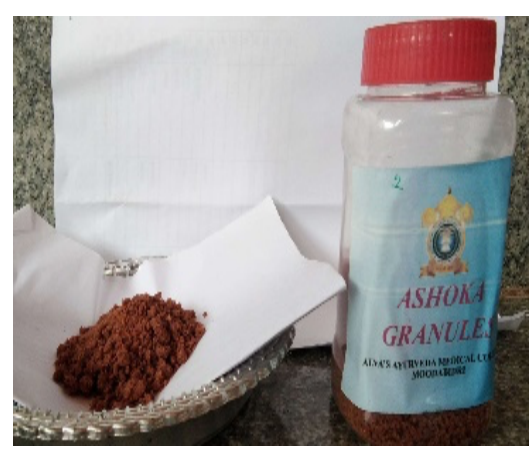

Ashoka Bark Granules

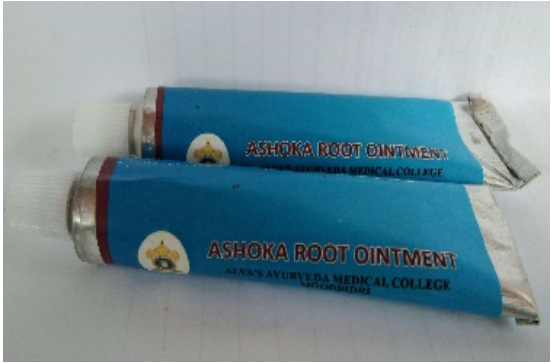

Root Ointment

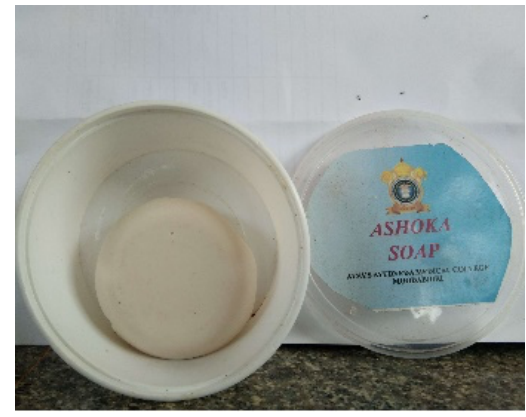

Stem powder Soap

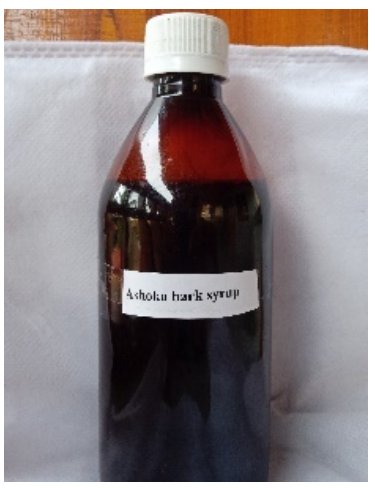

Bark syrup

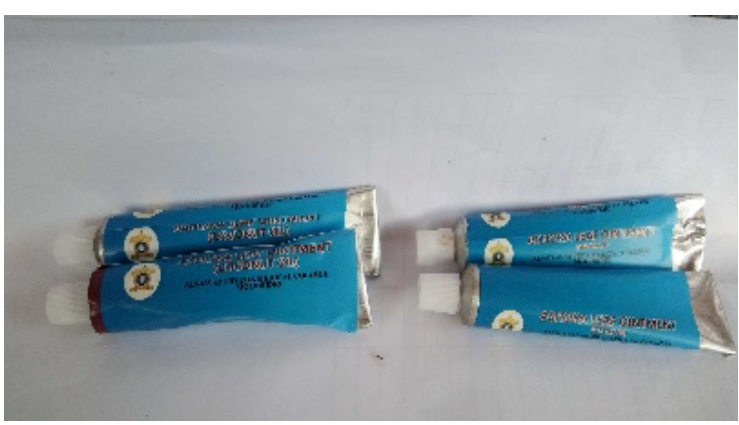

Leaf Ointment 


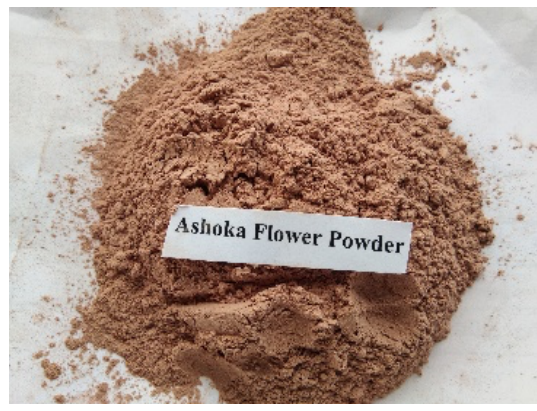

Flower Powder

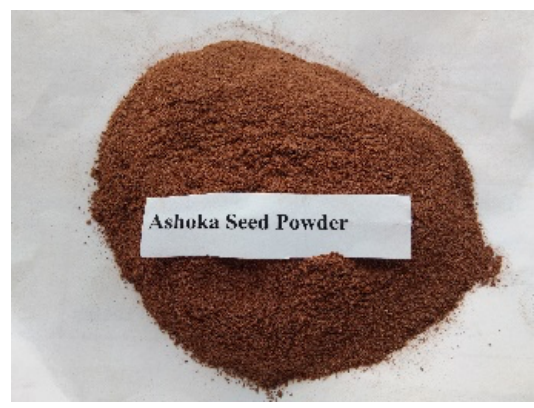

Seed Powder

\section{DISCUSSION}

Different parts of the plant Ashoka (S. asoca) are useful in various diseases as food and medicine. It controls various health-related problems manifested due to modern lifestyle such as irregular food habits, irregular sleep, spicy food, the stress in the working atmosphere etc. Such a potent medicinal plant is becoming extinct. If the therapeutic utility of the plant is explored, the cultivation of the same is also will increase for the benefit of mankind. Thus, we can develop the sustainable management and conservation of the plant as well in nature. In a nutshell, the outcome of the present study will be beneficial for society as most of the population are suffering from various ailments due to modern lifestyles.

In the current scenario, Ashoka bark has high demand in the pharmaceutical industry. Ayurvedic medicine manufacturers across the country use about 2,250 tonnes of Ashoka bark for manufacturing formulations to cure various gynaecological problems ${ }^{6}$. The ever-increasing demand for its phytochemicals, and over-exploitation of plant parts, attack of insects or pests on immature embryos is resulting in rapid depletion of the population in the wild. Due to the unscientific harvesting of the bark of $S$. asoca for medicinal uses, the species is under severe threat. $S$. asoca is almost extinct in the wild and is considered to be vulnerable ${ }^{7}$.

\section{Pharmaceutical Study}

\section{Ashoka Root Face Pack Powder}

The analytical studies of the face pack powder have shown the values within the normal range. A pilot clinical study was also conducted with 10 patients to analyse the therapeutic efficacy of the face pack powder in the blackish discolouration on the face, which has shown significant results. ${ }^{8}$

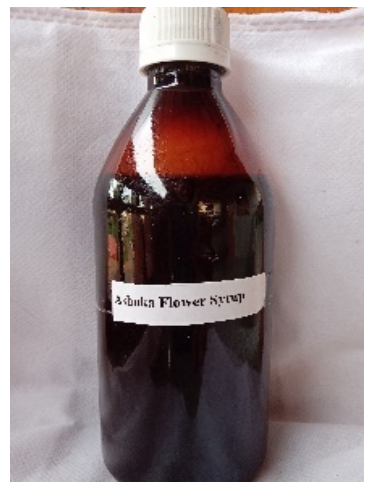

Flower syrup

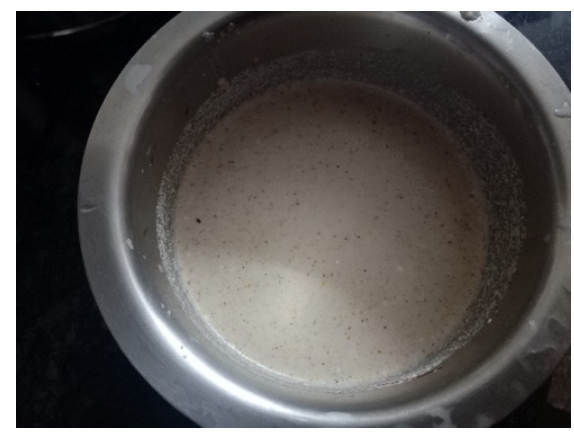

Prepared Tambuli as Food

\section{Ashoka Root Ointment}

A pilot clinical study was conducted with 10 patients to analyse the therapeutic efficacy of the root ointment in acne and blackish discolouration on the face, which has shown significant results. The ointment has shown a comparatively better result than the root powder face pack. The $\mathrm{pH}$ value of root ointment is 5.80 being slightly acidic, which lies within the normal $\mathrm{pH}$ of human skin i.e., between $5-6.5$. The results of viscosity give an idea about the measurement of strength and homogeneity confirms no lumps. The spreadability denotes the extent of the area to which the ointment spreads on application to the affected part. The value was found to be 13 , which shows its fast-spreading nature and good application.

\section{Ashoka Stem Syrup}

A pilot clinical study was conducted with 10 patients to analyse the therapeutic efficacy of the stem syrup in eczema and acne, which has shown significant results.

\section{Ashoka Stem powder Soap}

The bathing soap has shown significant results on skin diseases. Saponification value (or "Saponification number", also referred to as "sap" in short) represents the number of milligrams of potassium hydroxide or sodium hydroxide required to Saponify $1 \mathrm{~g}$ of fat under the conditions specified. It is a measure of the average molecular weight (or chain length) of all the fatty acids present. The long-chain fatty acids found in fats have low Saponification value because they have a relatively fewer number of carboxylic functional groups per unit mass of the fat as compared to short-chain fatty acids. The saponification value is then directly proportional to the fatty matter content. The saponification value of Ashoka stem oil is $178.30 \mathrm{mg} / \mathrm{gm}$.

\section{Ashoka Bark Kashaya}

Ashoka bark Kashaya is a well-known product for gynaecological disorders such as menorrhagia, metrorrhagia, leukorrhea, anaemia etc. 


\section{Ashoka Bark Syrup}

Ashoka bark Kashaya is modified into syrup form to improve palatability. A pilot clinical study was conducted with 10 patients to analyse the therapeutic efficacy of the stem bark syrup in dysfunctional uterine bleeding, which has shown not only styptic action but also shown improvement in the anaemic condition of the patient.

\section{Ashoka Bark Granules}

Ashoka bark granules were prepared by modifying the syrup to improve the palatability which may be given to the children to improve the strength in all aspects. When the syrup is heated, the moisture content of the mixture reduces, increasing the cohesive force and thereby imparts kinetic movement to the sugar molecules. When it is cooled, the sugar molecules coalesce due to the loss of kinetic movement. This is how the syrup is thickening and solidifying after cooling. For granule preparations, up to $60 \%-75 \%$ sugar is required. The completion of the syrup can be accessed when it reaches more than two-thread consistency ${ }^{9}$. This stage signifies less moisture content in the granules. In the present study, the Brix value or percentage of sugar is $66 \%$. The $\mathrm{pH}$ of the preparation was determined to check gastric irritation. In the present study, the $\mathrm{pH}$ of the granules is 6.70 which is slightly acidic. One important characteristic is tapped bulk density or tapped (tap) density. This means that the maximum packing density of a powder is achieved under the influence of externally applied forces. The minimum packed volume depends on several factors including particle size distribution and shape, true density and cohesiveness due to surface forces including moisture. Therefore, the tap density of a material is used to predict both its flow properties and its compressibility. Observed densities of samples are within the limit. The finer the particle size more will be the solubility and thus more will be the gastrointestinal absorption.

\section{Ashoka Tender Leaf Tambuli}

Tender leaves of Ashoka are ground with coconut and then added buttermilk and salt which is eaten during lunch by mixing with rice. It acts as a coolant to the body thereby useful in gastritis. It also contains proteins $12.28 \%$, carbohydrates $8.83 \%$ and vitamin C $1.24 \%$ which gives good nourishment to the body.

\section{Ashoka Leaf Ointment}

A pilot clinical study was conducted with 10 patients to analyse the therapeutic efficacy of the leaf ointment in Acne, which has shown significant results. The $\mathrm{pH}$ value of leaf ointment is 5.63 being slightly acidic, which lies within the normal $\mathrm{pH}$ of human skin i.e., between $5-6.5$. All the developed ointments were tested for homogeneity by visual inspection. They were tested for their appearance with no lumps. The spreadability denotes the extent of the area to which the ointment spreads on application to the affected part. The value was found to be 13, which shows its fastspreading nature and good application.

\section{Ashoka Flower Powder- Tambuli}

Flowers of Ashoka are ground with coconut, boiled with water and then added buttermilk and salt which is eaten during lunch by mixing with rice. It acts as a coolant to the body thereby useful in gastritis. It is also useful in anaemia, Menorrhagia etc. It contains a high amount of proteins $15.65 \%$, carbohydrates $24.55 \%$ and vitamin C $3.65 \%$ which gives good nourishment to the body. Anthocyanin is a flavonoid and its presence is seen only in flower samples. Flavonoids are the most important plant pigments in imparting yellow or red colour to the flower. This might be the reason for the bright orange to the yellow colour of Ashoka flowers. Flavonoids are the subgroup of phenolic compounds said to be the most common natural antioxidants and these antioxidants have a synergistic promotion on tyrosinase inhibition $^{10}$

\section{Ashoka Flower Syrup}

Ashoka flower syrup is prepared to improve palatability. The Brix value of the syrup is $55 \%$ which shows a moderate level of the sugar in the syrup shows good palatability. A pilot clinical study was conducted with 10 patients to analyse the therapeutic efficacy of the flower syrup in gastritis. which has shown significant results.

\section{Ashoka Seed Powder}

Seed powder of Ashoka is useful in urinary calculi and burning micturition. The carbohydrate level in the seed is $26.45 \%$. Potassium in the ash of the seed is responsible for the smooth functioning of the kidney, heart and muscles ${ }^{11}$.

\section{Pharmaceutico-Analytical Study}

\section{Refractive Index}

Refractive index is a fundamental physical property of a substance often used to identify a particular substance, confirm its purity, or measure its concentration. When a ray passes through one medium to another medium of different densities, it is bent from the original path. Thus, the ratio of the velocity of light in a vacuum to its velocity in a substance is termed the refractive index of the second medium. Depending upon purity, it's constant for a liquid and can be considered as one of its standardization parameters. The Refractive index of a compound varies with the wavelength of the incident light, temperature and pressure.

\section{Brix Value}

Brix is a measure of the number of dissolved solids in a liquid via its specific gravity and is used especially to measure dissolved sugar. One degree of Brix is $1 \mathrm{gm}$ of sucrose in 100 grams of solution. A refractometer determines the degrees of Brix by measuring the refraction of light passing through a liquid sample. Liquids containing sugar are denser than water and cause greater refraction as light passes through. The instrument compares this to the refraction of light through water and provides a Brix value.

\section{Iodine value}

Iodine value indicates the degree of unsaturation of oil; the greater the degree of unsaturation higher will be the possibility of absorption and atmospheric oxidation leading to rancidity. The more iodine number, the more unsaturated fatty acid bonds are present; unsaturated fatty acid is better absorbed than saturated fatty acids.

\section{Saponification value}

The saponification value is a measure of the average molecular weight of all the fatty acids present. The long-chain fatty acids found in fats have low Saponification value because they have a relatively fewer number of carboxylic functional groups per unit mass of the fat as compared to short-chain fatty acids.

\section{Viscosity}

Viscosity is an index of resistance offered by the surface to flow a liquid; the higher the viscosity of a liquid, the greater is the resistance to flow, if the viscosity of the oil preparation is increased, the rate of absorption decreases. If oil is less viscous this means the rate of absorption is very much high.

\section{Rancidity Test: (Kreis test)}

Mix $1 \mathrm{ml}$ of melted fat and $1 \mathrm{ml}$ of Conc. $\mathrm{HCl}$ acid in a test tube. Add $1 \mathrm{ml}$ of a $1 \%$ solution of phloroglucinol in diethyl ether and mix thoroughly with the fat-acid mixture. A pink colour 
formation indicates that the fat is slightly oxidized while red colour indicates that fat is oxidized.

In the present study, it can be conclusively said that the face pack of the root powder is beneficial in blackish discolouration of the face, root ointment in acne and blackish discolouration of the face, stem syrup is beneficial in eczema and acne, stem powder soap is useful in skin disease, bark kashaya in gynaecological disorders, bark syrup in dysfunctional uterine bleeding and anaemia, bark granules in general debility and anaemia, tender leaves Tambuli in gastritis, leaf ointment in acne, flower Tambuli in gastritis and menorrhagia, flower syrup in gastritis and seed powder is useful in urinary calculi and burning micturition. The multiple formulations of different parts of Ashoka ( $S$. asoca) which are useful as food and medicine are the outcomes of the present study. The study mainly focused on phytochemical and pharmaceutical studies. Further, clinical study on large scale will be beneficial to conclude its utility in various disorders.

\section{CONCLUSION}

Since the plant Ashoka is fast eroding and becoming extinct, conservation is very important. Therefore, the cultivation and conservation of Ashoka ( $S$. asoca) should be encouraged all over India by the Government of India through National Medicinal Plants Board. The different recipes documented in the present study should be analysed for their nutritional value and health benefits.

\section{ACKNOWLEDGEMENT}

The authors are acknowledging the National Medicinal Plants Board for sponsoring and encouraging the research project entitled "Ethno Medical Documentation and Value addition of Different Parts of Ashoka [Saraca asoca Roxb. de Wilde] through Standard Operative Procedure (SOP)". The authors also express their gratitude to the folklore informants for revealing the secrecy of their experience for the benefit of mankind.

\section{REFERENCES}

1. Anonymous, General Guidelines for Methodologies on Research and Evaluation of Traditional Medicine, World Health Organization, Geneva 2000. p 21.

2. Soumya Saraswathi, Subrahmanya Padyana. Physicochemical and Phytochemical study on different parts of Ashoka, World Journal of Pharmaceutical Research, 2021;10 (8):1009-1018.

3. Anonymous, The Ayurvedic Pharmacopoeia of India, Part 1, Vol 1, First edition 1990, Government of India, New Delhi. p 17-18.

4. Anonymous, Indian Pharmacopoeia, The Controller of Publishers, Department of H \& FW, Govt. of India, New Delhi. 2007. p 199-202.

5. Sadasivam S. and Manickam A. Biochemical methods, 3rd edition, New age international (P) Ltd., Publishers, New Delhi. 1991. p89.

6. https://www.iasabhiyan.com/list-of-rare-and-endangeredindian-plants

7. Srivastava N, Bagchi D, Srivastava K. Pharmacognosy of Ashoka Stem Bark and its Adulterants, International Journal of Crude Drug Res., 1988; 26(2): 65-72.

8. Anonymous (1998) Quality control methods for medicinal plant materials. WHO, Geneva, p. 46.

9. Gokarna R, Rajput D, Rathi B, Wanjari A. Pharmaceutical standardization of Shatavari granules J Indian Syst Med 2015;3:54.

10. Anupam Bisht et al. Pharmacognostical studies on Saraca asoca Roxb. Willd. Flower. An International Journal on tropical plant Research, 2017;4(1):153-160

11. Sasmal S et al. Pharmacognostical, phytochemical and pharmacological evaluation for the antipyretic effect of the seeds of Saraca asoca Roxb. Asian Pacific Journal of Tropical Biomedicine, 2012;2(10):782-786.

\section{Cite this article as:}

Soumya Saraswathi $M$ and Subrahmanya Padyana. Pharmaceutical and analytical study on different parts of Ashoka [Saraca asoca Roxb. De wilde.]. Int. J. Res. Ayurveda Pharm. 2021;12(5):27-34 http://dx.doi.org/10.7897/2277-4343.1205137 